\title{
THE RATE OF METABOLISM OF THE SPINY RAT, PROECHIMYS SEMISPINOSIS, WITH COMMENTS ON THE ECOLOGICAL FACTORS THAT INFLUENCE THE BASAL RATE OF METABOLISM IN RODENTS AND LAGOMORPHS ${ }^{\text {}}$
}

\author{
BRIAN K. McNAB \\ Department of Zoology, University of Florida, Gaines- \\ ville, Florida 32601
}

A TAXA DE METABOLISMO DE PROECHIMYS SEMISPINOSIS, COM COMENTÁRIOS SOBRE OS FATORES ECOLÓGICOS QUE INFLUENCIAM A TAXA BASAL DE METABOLISMO EM RODENTIA E LAGOMORPHA

\section{SUMĀRIO}

O metabolismo foi medido no rato-de-espinho, Proechimys semispinosis, que é tropical em distribuição e de hábito frugivoro. O peso é o fator mais importante na determinação do nível do metabolismo. Proechimys tem um valor que é um pouco mais alto do que é o esperado em relação ao seu peso. Muito da variação do metabolismo independente de peso, em roedores e coelhos, resulta dos hábitos e da distribuição dessas espécies. Necessitamos de mais estudos de espécies tropicais para avaliar a influência do clima e restrição alimentar na região tropical.

\section{SUMMARY}

The rate of metabolism was measured in the tropical, fruiteating spiny rat, Proechimys semispinosis. Proechimys has a rate above that expected from weight which may reflect feeding upon a stable, abundant food resource. Although body weight is the most important factor determining the level of the basal rate of metabolism, much of the weight independent variation in basal rates in rodents and lagomorphs can be accounted for by their habits and distribution. Much more information is needed from tropical species.

1 Dedicado ao Prof. Paulo Sawaya, que me introduziu as riquezas biológicas brasileiras.

Número especial $\epsilon m$ homenagem ao Prof. Dr. Paulo Sawaya, no ano jubilar de seu magistério. 


\section{INTRODUCTION}

Ever since Kleiber described the influence of body weight on the basal rate of metabolism in mammals in 1932, it has become increasingly clear that body weight is the one most important factor determining the level of the basal rate. That is not to say that body weight is the only factor of importance. Ecological relations, especially food habits (McNab, 1969), microclimate (McNab, 1966), and macroclimate (McNab and Morrison, 1963) also affect the basal rate in mammals.

Phylogeny complicates all studies that attempt to determine the influence of the environment on an animal's characteristics. Since closely related species often have similar habits, distributions, and weights, it is not surprising that they often have similar basal rates of metabolism. Some authors (Martin, 1903; Eisentraut, 1960; Cade, 1964) have concluded that this similarity is primarily phylogenic, although there is little evidence that this is so independent of habits, distribution, and weight.

This short paper reports on a few data taken on the metabolism of a tropical, fruit- and seed-eating rodent (Proechimys semispinosis) and compares its basal rate with those of other rodents in an attempt to determine the effect of food habits and distribution.

\section{METHODS}

Spiny rats, Proechimys semispinosis, were collected in the seasonally humid rain-forest of Barro Colorado Island, Canal Zone, Panama. Oxygen consumption was measured in an open system using a Beckman paramagnetic oxygen analyzer and was recorded as STP. Body temperature was measured with a YSI telethermometer at the termination of each measurement of oxygen consumption.

\section{RESULTS AND DISCUSSION}

The temperature relations of oxygen consumption and body temperature in Proechimys are shown in Figure 1. Basal rate of metabolism is equal to $076 \mathrm{ccO}_{2} / \mathrm{g}-\mathrm{hr}$, which is about $6 \%$ greater than is expected for a $498 \mathrm{~g}$ mammal from Kleiber's average curve. Scholan- 
RATE OF METABOLISM $\left(\mathrm{CcO}_{2} / \mathrm{g}-\mathrm{hr}\right)$

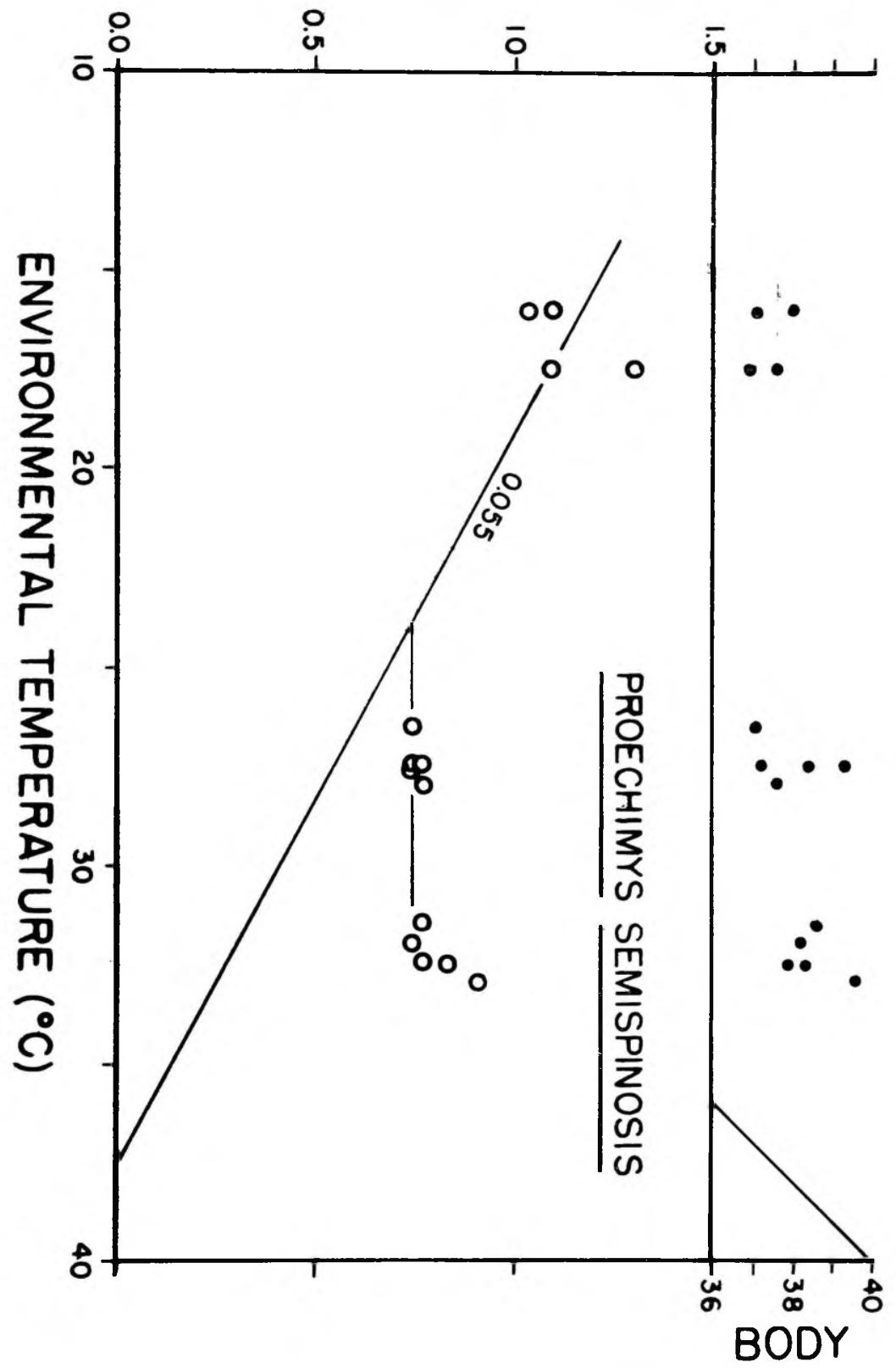

TEMPERATURE $\left({ }^{\circ} \mathrm{C}\right)$

Fig. 1 - Body temperature and rate of oxygen consumption as a function of environmental temperature in the three spiny rats, Proechimys semispinosis. 


\section{BASAL RATE OF METABOLISM, $\mathrm{M}_{\mathrm{b}} / \mathrm{W}\left(\mathrm{CcO}_{2} / \mathrm{g}-\mathrm{hr}\right)$}

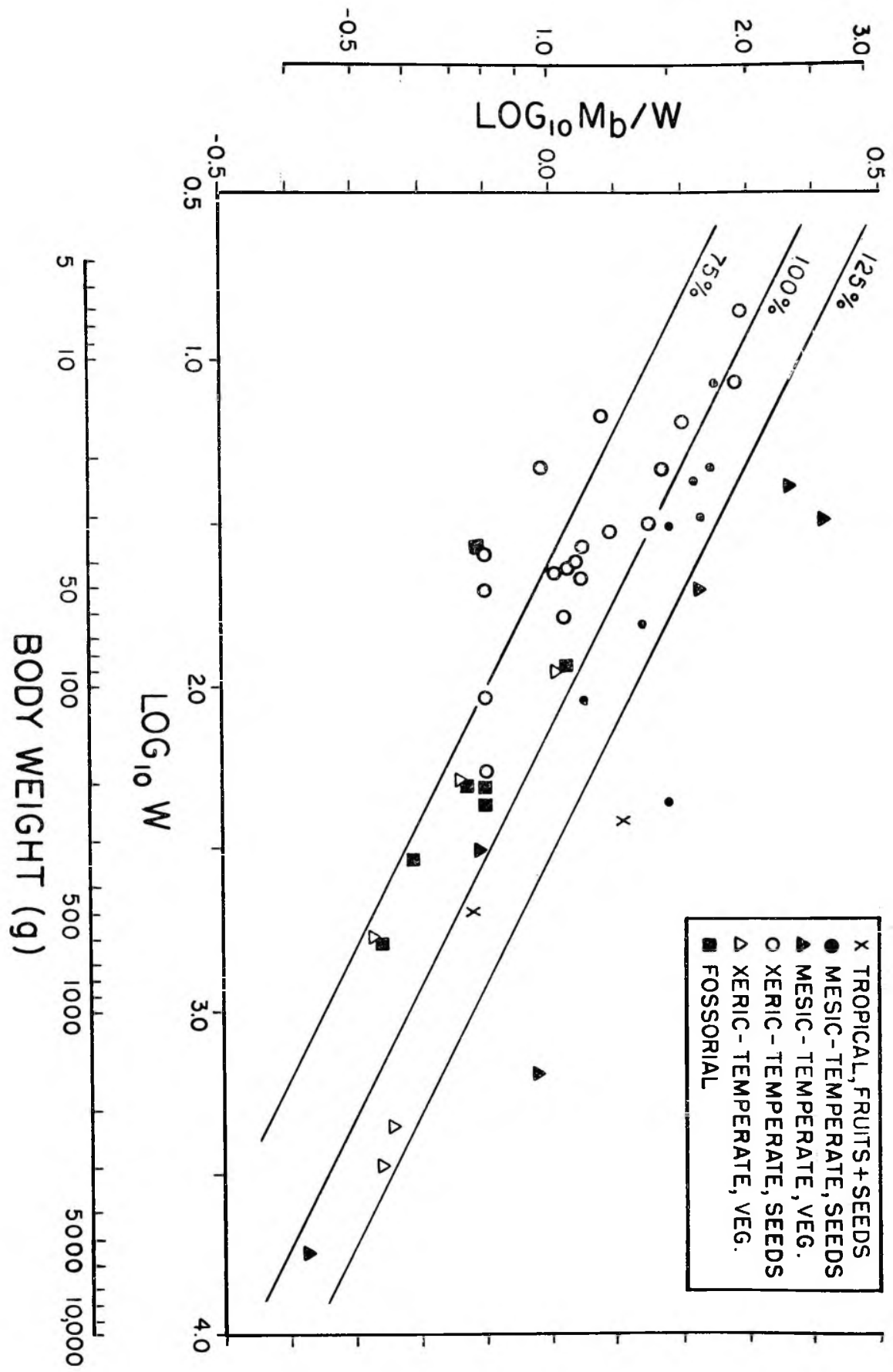

Fig. 2 - The relation between the basal rate of metabolism and body weight in rodents and lagomorphs. Kleiber's mean curve (1932) is represented by the curve labelled $100 \%$. Two other curves, one $25 \%$ higher, are also shown. 
der et al. (1950b) found that Proechimys had a basal rate that was $50 \%$ greater than expected from body weight. Thermal conductance in Proechimys is equal to $0.055 \mathrm{ccO}_{2} / \mathrm{g}-\mathrm{hr}{ }^{\circ} \mathrm{C}$, which is $28 \%$ greater than expected from the weight-dependent relation of Herreid and Kessel (1967). The high conductance is presumably related to the occurrence of the spiny rat in the thermally mild, tropical rain-forest (compared to the cool or cold temperate species assembled by Herreid and Kessel).

It is not immediately clear why this species should have a high basal rate of metabolism. However, tropical fruit-eating bats also have high basal rates of metabolism ( $\mathrm{McNab}, 1969)$. These high rates were explained by 1 ) the suggestion that the metabolism of mammals feeding on a dependable food supply is higher than that of species that feed on a seasonally undependable food supply, and 2) the observation that fruit tends to be available throughout the year in a tropical rain-forest. The spiny rat also appears to conform to this interpretation.

Data on the basal rates of metabolism of rodents and lagomorphs have been assembled in Table 1 and Figure 2. Again, it is apparent that body weight is the one most important factor setting the level of the basal rate (Figure 2). But there is a pattern to the dispersion of species about the mean curve. The following trends can be noted. 1) Rodents from mesic temperate environments have basal rates equal to or greater than those expected from weight, irrespective of their food habits. 2) The highest basal rates, independent of weight, are found in species from cold-temperate or arctic regions (e.g. Microtus, Clethrionomys, Dicrostronyx, Tamaisciurus, and Lepus americanus). 3) Rodents that are found in xeric environments have low basal rates of metabolism, whether they feed on vegetation or on seeds. The desert hares of the genus Lepus, however, have basal rates greater than those expected from weight. Yet even these Lepus have a lower rate of metabolism, relative to body weight, than is found in the coldtemperate snowshoe hare, Lepus americanus. 4) Fossorial rodents have low basal rates of metabolism irrespective of body size; the reduction is the greatest in the naked mole-rat (Heterocephalus), which is found in a hot, arid environment. 5) Rodents that regularly go into torpor have lower basal rates than related or similar species that do not go into torpor (e.g. Perognathus vs. Dipodomys, Spermophilus vs. Ammospermophilus). 
These correlations between the weight-independent variation in the basal rate of metabolism and the habits and distributions of rodents and hares can be explained by the following considerations. 1) Cold temperate and arctic species must maintain appreciable temperature differentials between the body and the environment, even when subniveal microenvironments are used. It has been shown (McNab, 1970) that the ability of an endotherm to maintain a $\Delta T$ is proportional to the ratio of the basal rate of metabolism to thermal condunctance, or

$$
T_{b}-T_{l}=\Delta T=M_{b} / C,
$$

where $T_{b}$ is body temperature, $T_{l}$ is the lower limit of thermoneutrality, $M_{b}$ is the basal rate, and $C$ is thermal conductance. This differential can be increased by both an increased $M_{b}$ and a decreased $C$. It has been long known that mammals found in cold environments have good insulation, that is, poor conductance (Scholander et al., 1950a). The data assembled in this paper also show that rodents contribute to a high $T_{b}$ in a cold climate - that is, a high $\Delta T$ - by a high basal rate of metabolism.

2) Mammals living in an arid environment face the problem of balancing their water budget. Since many species use foods of a low water content, e.g. seeds, these rodents must reduce water expenditures. Such reductions may be produced by remarkable renal modifications (e.g. MacMillan and Lee, 1967), but also may involve a reduced energy expenditure, since the rate of respiratory water loss depends upon the rate of gas exchange (Gleen, 1970). Thus, the greatest reductions occur in such desert-inhabiting genera as Microdipodops and Perognathus.

3) Fossorial rodents have low basal rates of metabolism, which seems to be related to the problem of overheating in burrows that are saturated with moisture, since a low $M_{b}$ will reduce body temperature and thus will reduce the possibility of overheating ( $\mathrm{McNab}$, 1966).

Clearly, ecological factors are important in determining the basal rate of metabolism of rodents. One cannot deny that there may also be a subtile phylogenetic component to this determination other than that correlated with ecology and body size. Thus, it presently appears that ground squirrels, regardless of environment, may be 
typified by low basal rates; yet, even this tendency may in some way reflect their propensity for estivation and hibernation.

Unfortunately, little is known of tropical rodents. The great array of fruit- and seed-eating caviomorphs in the neotropics is nearly completely unstudied; this is especially unfortunate because of their great size range. It is hoped that this small note will stimulate such research to better clarify the manner in which ecological strategy influences energy expenditure.

\section{A C K N O W L E D G E E N T S}

I should like to express my gratitude to the Smithsonian Tropical Research Institute for the use of laboratory facilities at Barro Colorado Island, Panama Canal Zone. Mrs. Joanna Gliwicz was very helpful in procurring the spiny rats and we had many stimulating discussion on the energetics of mammals in the field. I should also like to thank Mrs. Paul Laessle for drawing the graphs. This work was supported by a grant from the National Science Foundation (GB 20689).

\section{R E F E R E N C E S}

BARTHOLOMEW, G. A. and R. E. MacMILLEN (1961) - Oxygen consumption estivation, and hibernation in the kangaroo mouse, Microdipodops pallidus. Physiol. Zool., 34:177-183.

BAUDINETTE, R. V. (1972) - Energy metabolism and evaporative water loss in the California ground squirrel. J. Comp. Physiol., 81:57-72.

BROWN, J. H. (1968) - Adaptation to environmental temperature in two species of woodrats, Neotoma cinerea and N. albigula. Misc. Publ. Mus. Zool., Univ. Mich., 135:1-48.

CODE, T. J. (1964) - The evolution of torpidity in rodents. Ann. Acad. Sci. Fenn. A, IV, 71:79-112.

CARPENTER, R. E. (1966) - A comparison of thermoregulation and water metabolism in the kangaroo rats Dipodomys agilis and Dipodomys merriami. Univ. Calif. Publ. Zool., 78:1-36.

DAWSON, T. J. and K. SCHMIDT-NIELSEN (1966) - Effect of thermal conductance on water economy in the antelope jack rabbit, Lepus alleni. J. Cell. Comp. Physiol. 67:463-472.

EISENTRAUT, M. (1560) - Heat regulation in primitive mammals and in tropical species. Bull. Mus. Comp. Zool., 124:31-43.

GLENN, M. E. (1970) - Water relations in three species of deer mice (Peromyscus). Comp. Biochem. Physiol., 33:231-248.

GORECKI, A. (1968) - Metabolic rate and energy budget in the bank vole. Acta Ther., 13:341-365. 


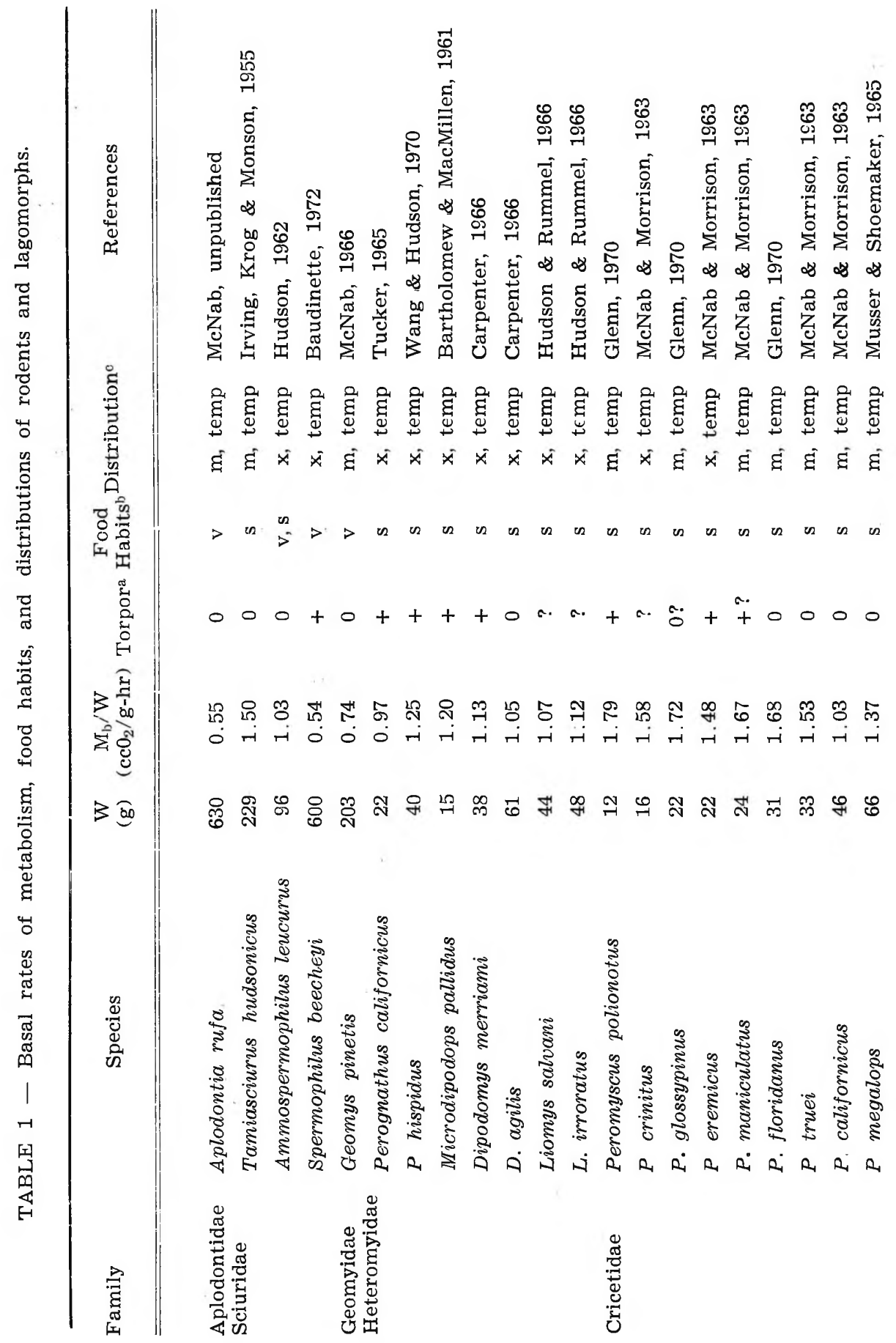


通

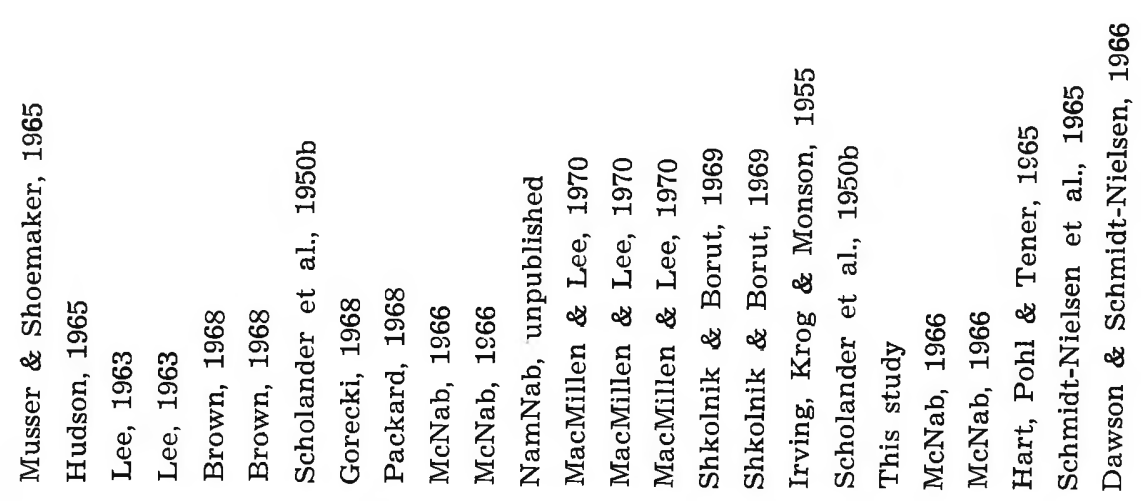

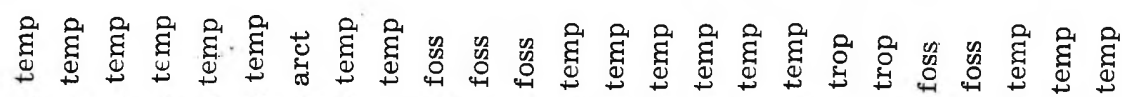

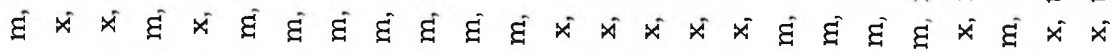

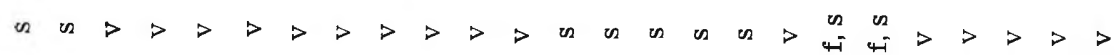

$0+00000000000000000000000$

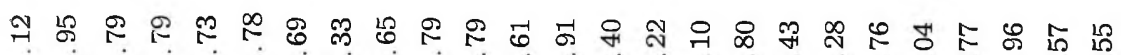

-

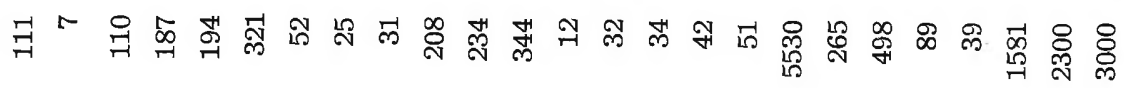

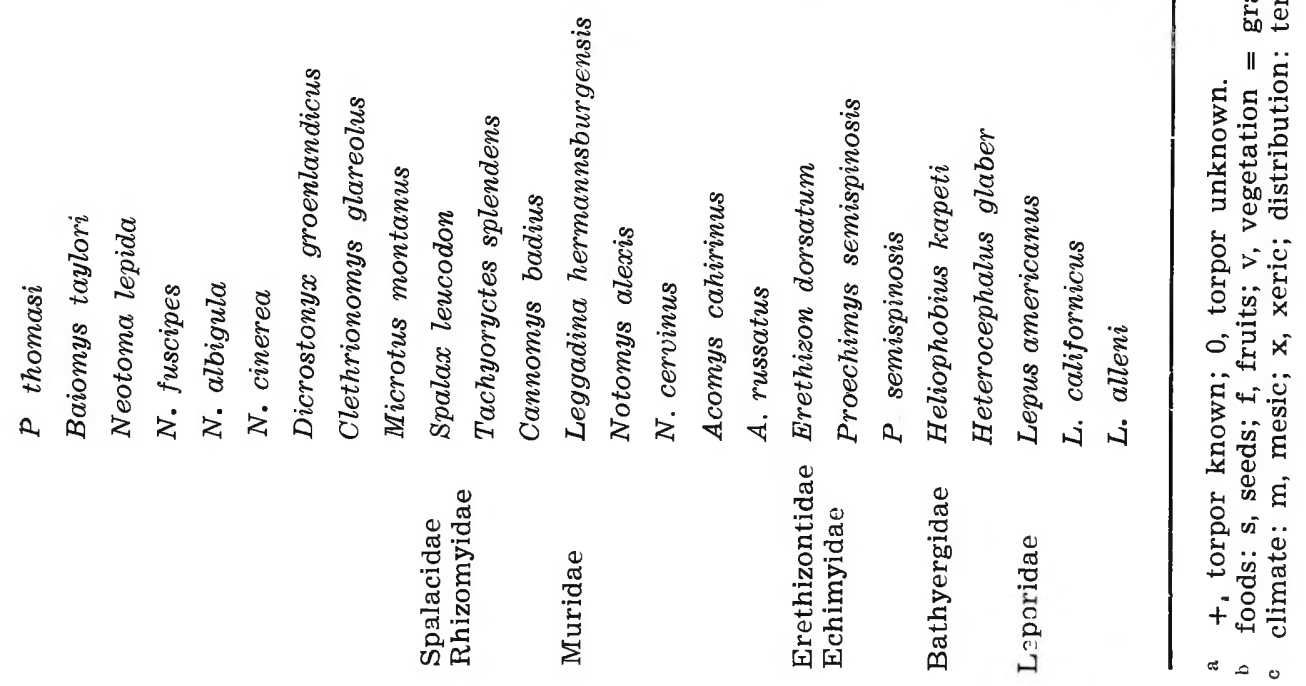


HART, J. S.; H. POHL and J. S. TENER (1965) - Seasonal acclimation in varying hare (Lepus americanus). Can. J. Zool., 43:731-744.

HERREID, C. F., II and B. KESSEL (1967) - Thermal conductance in birds and mammals. Comp. Biochem. Physiol., 21:405-414.

HUDSON, J. W. (1962) - The role of water in the biology of the antelope ground squirrel, Citellus leucurus. Univ. Calif. Publ. Zool., 64:1-56.

HUDSON, J. W. (1965) - Temperature regulation and torpidity in the pigmy mouse, Baiomys taylori. Physiol. Zool., 38:243-254.

HUDSON, J. W. and J. A. RUMMEL (1966) - Wat $€$ r metabolism and temperature regulation of the primitive heteromyids, Liomys salvani and Liomys irroratus. Ecology, 47:345-354.

IRVING, L.; H. KROG and M. MONSON (1955) - The metabolism of some Alaskan animals in winter and summer. Physiol. Zool,, 28:173-185.

KLEIBER, M. (1932) - Body size and metabolism. Hilgardia, 6:315-353.

LEE, A. K. (1963) - The adaptations to arid environments in wood rats of the genus Neotoma. Univ. Calif. Publ. Zool., 64:57-\$6.

MARTIN, C. J. (1903) - Thermal adjustment and respiratory exchange in monotremes and marsupials. Phil. Trans. Roy. Soc. London, B, 195:1-37.

MacMILLEN, R. E. and A. K. LEE (1967) - Australian desert mice: independence of exogenous water. Science, 158:383-385.

MacMilLEN, R. E. and A. K. LEE (1970) - Energy metabolism and pulmocutaneous water loss of Australian hopping mice. Comp. Bioch $€ \mathrm{~m}$. Physiol., 35:355-369.

McNAB, B. K. (1966) - The metabolism of fossorial rodents: A study of convergence. Ecology, 47:712-733.

McNAB, B. K. (1969) - The economics of temperature regulation in neotropical bats. Comp. Biochem. Physiol., 31:227-268.

McNAB, B. K. (1970) - Body weight and the energetics of temperature regulation. J. Exp. Biol., 53:329-348.

McNAB, B. K. and P. R. MORRISON (1963) - Body temperature and metabolism in subspecies of Peromyscus from arid and mesic environments. Ecol. Monographs, $33: 63-82$.

MUSSER, G. G. and V. H. SHOEMAKER (1955) - Oxygen consumption and body temperature in relation to ambient temperature in the Mcxican deer mice, Peromyscus thomasi and $P$. megalops. Occ. Papers Mus. Zool., Univ. Mich., 643:1-15.

PACKARD, G. C. (1968) - Oxygen consumption of Microtus montanus in relation to ambient temperature. J. Mammal., 49:215-220.

SCHMIDT-NIELSEN, K.; T. J. DAWSON; H. T. HAMMEL; D. HINDS and D. C. JACKSON (1965) - The jack rabbit - a study in its desert survival. Hvalrådets Skifter, 48:125-192. 
SCHOLANDER, P. F.; V WALTERS; R. HOCK and L. IRVING (1950a) Body insulation of some arctic and tropical mammals and birds. Biol. Bull., $99: 225-236$.

SCHOLANDER, P. F.; R. HOCK; V. WALTERS and L. IRVING (1950b) Adaptation to cold arctic and tropical mammals and birds in relation to body temperature, insulation, and basal metabolic rate. Biol. Bull., 99:259-271.

SHKOLNIK, A. and A. BORUT (1969) - Temperature and water relations in two species of spiny mice (Acomys). J. Mammal., 50:245-255.

TUCKER, V. A. (1965) - Oxygen consumption, thermal conductance, and torpor in the California pocket mouse, Perognathus californicus. J. Cell. Comp. Physiol., 65:393-404.

WANG, L. C. and J. W. HUDSON (1970) - Some physiological aspects of temperature regulation in the normothermic and torpid hispid pocket mouse, Perognathus hispidus. Comp. Biochem. Physiol., 32:275-293. 
$-\quad 1$ this

$\therefore$ ay $\therefore !$

$\therefore \quad$. 